Vegetalika. 2018. 7(1): 26-38

\title{
Pengaruh Pemeraman Eksplan Daun dengan Kolkisina Secara In Vitro terhadap Keberhasilan Pembentukan Terung Tetraploid
}

\section{Effect of Colchicine In Vitro Leaf Explant Treatment on Polyploidization of Eggplant}

\author{
Fathin Nabihaty ${ }^{1)}$, Taryono ${ }^{\left.2^{*}\right)}$, Rani Agustina Wulandari²) \\ 1) Program Studi Pemulian Tanaman, Fakultas Pertanian, Universitas Gadjah Mada \\ 2) Departemen Budidaya Pertanian, Fakultas Pertanian, Universitas Gadjah Mada \\ *) Penulis untuk korespodensi E-mail: tariono60@gmail.com
}

\begin{abstract}
Plant improvement to increase commercial value of eggplant could be done through polyploidization. In vitro colchicine treatment has a potential to increase polyploidization efficiency. An experiment to study effect of incubation period of colchichone treatment on eggplant leaf explant had done, including polyploidization success and tetraploid (4x) formation which morphologically and cytologically indicated. Three incubation periods with $2.5 \mathrm{mM}$ colchicine $(24,48$, and 72 hours) and control were tested on five eggplant genotypes (Rimbang, Lokal Bantul, Pipit, Hijau Malang, and Limao) arranged in completely randomized design. The main prosedures are pre-treatment, incubation with colchicine, regeneration, sub-culture 1-6 times, rooting, and re-regeneration up to 2 times. This procedure successfully formed some polyploids of Rimbang, consists of $2 x$ $+3 x$ and $3 x+4 x$. Amount of polyploids was estimated at 59\%. Plantlet containing tetraploid cells as well as the highest ploidy obtained from 72 hours colchicine treatment.
\end{abstract}

Key words: eggplant, colchicine, in vitro, polyploidization

\section{INTISARI}

Perbaikan tanaman untuk meningkatkan daya tawar terung dapat dilakukan melalui poliploidisasi. Pemberian kolkisina secara in vitro berpeluang meningkatkan efisiensi poliploidisasi. Penelitian dilakukan untuk mengkaji pengaruh pemeraman eksplan daun dengan kolkisina secara in vitro terhadap keberhasilan poliploidisasi dan pembentukan terung tetraploid (4x), serta mendapatkan tetraploid berdasarkan ciri morfologi planlet dan jumlah kromosom. Tiga aras periode peram dengan 2,5 mM kolkisina $(24,48$, dan 72 jam) dan satu perlakuan pemeraman tanpa kolkisina sebagai pembanding, diujicobakan pada lima jenis terung (Rimbang, Lokal Bantul, Pipit, Hijau Malang, dan Limao) menggunakan rancangan acak lengkap. Tahap utama yang dilalui eksplan yaitu pra-pemeraman, pemeraman dengan kolkisina, regenerasi, penggantian media tanam 1-6 kali, pengakaran, dan regenerasi ulang hingga 2 kali. Tata cara ini berhasil membentuk Terung Rimbang poliploid yang terdiri dari $2 x+3 x$ dan $3 x+4 x$. Jumlah individu poliploid diperkirakan sebanyak $59 \%$, sisanya $41 \%$ merupakan diploid. Planlet yang memiliki sel tetraploid sekaligus ploidinya tertinggi diperoleh dari pemeraman kolkisina selama 72 jam.

Kata kunci: in vitro, kolkisina, poliploidisasi, terung 


\section{PENDAHULUAN}

Perbaikan tanaman diperlukan untuk meningkatkan nilai tambah dan daya jual terung. Perbaikan tanaman yang difokuskan untuk pembentukan buah terung tanpa biji (partenokarpi) akan dapat menjawab tuntutan konsumen yang menginginkan adanya buah terung tanpa biji dengan kualitas lebih baik dan produktivitas tinggi. Partenokarpi genetis biasanya dihasilkan secara alami dari tanaman poliploid dengan genom ganjil, khususnya pada tanaman triploid. Menurut Kihara (1951), partenokarpi dari tanaman triploid dapat diinduksi melalui manipulasi ploidi yang ditempuh dengan persilangan biasa antara tanaman diploid dengan tetraploid menghasilkan hibrid triploid, yang kemudian menghasilkan buah tanpa biji (seedless). Program ini dapat sekaligus menjadi upaya peningkatan mutu dan jumlah serta sifat-sifat lain yang diinginkan bagi pengembangan usaha budidaya terung.

Menurut Pardal (2009), persilangan dalam upaya pembentukan partenokarpi akan lebih praktis dan permanen jika telah berhasil diperoleh tanaman tetraploid. Poliploidisasi diperlukan untuk ini karena tanaman terung normal biasanya merupakan diploid dengan kromosom $2 n=2 x$. Mutagen kimia yang paling umum digunakan untuk ini adalah kolkisina (Dhooghe et al., 2011).

Pemberian kolkisina menggunakan protokol budidaya tanaman secara in vitro memiliki potensi besar untuk meningkatkan efisiensi poliploidisasi karena lingkungan yang lebih terkendali dan terstandar dari pada perlakuan dalam rumah kaca. Poliploidisasi in vitro juga telah menjadi metode yang dibakukan dalam budidaya jaringan sejak 1990-an (Dhooghe et al., 2011). Selain itu, terung adalah salah satu anggota Solanaceae yang merupakan tanaman model dalam budidaya jaringan, sehingga poliploidisasi in vitro tanaman terung juga diperlukan bagi pengembangan teknik poliploidisasi in vitro tanaman lain. Penelitian ini bertujuan untuk mengetahui pengaruh pemeraman eksplan daun dengan kolkisina secara in vitro terhadap keberhasilan poliploidisasi dan pembentukan terung tetraploid, serta mendapatkan individu tetraploid berdasarkan ciri morfologi planlet dan jumlah kromosom.

\section{BAHAN DAN METODE}

Bahan tanam berupa daun dari planlet in vitro lima jenis terung, yaitu (Gambar 1) Rimbang (R), Pipit (TP), Lokal Bantul (LB), Hijau Malang (THM), dan Limao (L). Percobaan untuk masing-masing jenis terung dilakukan terpisah menggunakan rancangan acak lengkap. Tiga waktu pemeraman kolkisina (24, 48 dan 72 jam) digunakan sebagai perlakuan, dan kontrol tanpa pemeraman kolkisina digunakan 
Fathin Nabihaty et al., / Vegetalika. 2018. 7(1): 26-38

sebagai pembanding. Formulasi larutan media terdiri dari $\mathrm{MS}+7 \mathrm{~g} / \mathrm{l}$ agar-agar. Media Perlakuan (MP) ditambahkan 2,5 mM kolkisina tanpa ZPT; Media Regenerasi (MRT) ditambahkan 1 mg/l IBA + 3 mg/l BAP; Media Pengakaran (MA) ditambahkan 1 mg/l IBA. Formulasi ZPT untuk media regenerasi ini sebelumnya telah diuji oleh Erniwitama (2013). Penambahan sukrosa untuk MP dan MRT sebanyak $25 \mathrm{~g} / \mathrm{l}$, sedangkan MA sebanyak $30 \mathrm{~g} / \mathrm{l}$.
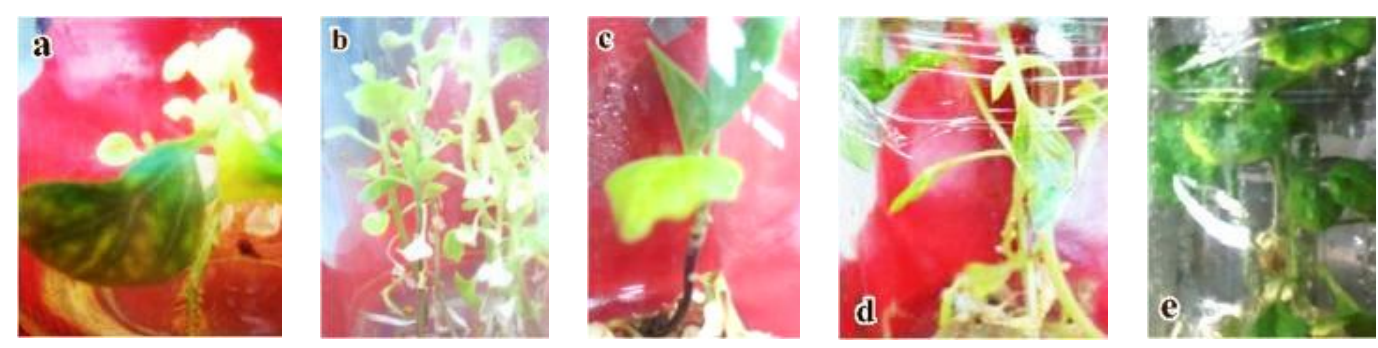

Gambar 1. Planlet induk (a) Terung Limao, (b) Terung Hijau Malang, (c) Terung Lokal Bantul, (d) Terung Pipit, dan (e) Terung Rimbang yang digunakan sebagai sumber eksplan

Tahap utama yang dilalui eksplan yaitu pra-pemeraman di media MRT, kemudian perlakuan di media MP, dan diregenerasikan di media MRT. Penggantian media regenerasi dilakukan setiap lima minggu, setelah itu dilakukan pengakaran di media MA, dan jika memungkinkan dilakukan regenerasi ulang. Pengamatan kualitatif dan kuantitatif dilakukan terhadap daya regenerasi (frekuensi regenerasi dan pertunasan), serta morfologi planlet (tinggi tunas, jumlah nodus daun, bentuk daun, warna daun, dan panjang akar). Frekuensi Regenerasi (FR) dihitung dengan pendekatan:

$$
\mathrm{FR}=\frac{\text { Jumlah Eksplan Berplanlet }}{\text { Jumlah Eksplan Awal }} \times 100 \% \quad \ldots \text { (1) }
$$

Data morfologi dan regenerasi dianalisis secara deskriptif dan digunakan sebagai kriteria awal seleksi poliploid, planlet kotrol sebagai pembanding. Individu yang diduga poliploid dihitung jumlah kromosomnya menggunakan metode squash acetocarmin (Collins, 1979) dan mikroskop cahaya untuk mengetahui keberadaan tetraploid sekaligus sebagai pembuktian keberhasilan poliploidisasinya. Efisiensi Poliploidisasi (EP) dihitung dengan metode Dhooghe et al. (2011):

$$
\mathrm{EP}=\frac{\text { Jumlah planlet poliploid }}{\text { Jumlah planlet bertahan hidup }}
$$




\section{HASIL DAN PEMBAHASAN}

Telah banyak laporan yang menyebutkan bahwa kolkisina dosis tertentu menyebabkan kematian sel, penurunan daya regenerasi dan tingkat ketahanan hidup planlet. Hasil serupa diperoleh dalam penelitian yang menggunakan dosis kolkisina 2,5 $\mathrm{mM}$ ini. Dari keseluruhan 45 eksplan terung yang dipaparkan dengan kolkisina dengan 3 kali siklus regenerasi hanya diperoleh 113 individu dari jenis Rimbang yang berhasil membentuk planlet dengan rerata frekuensi regenerasi $59,5 \%$. Namun demikian, nilai ini masih jauh lebih besar dibanding rerata kontrol yang hanya 37,8\% (Tabel 1). Hal ini menunjukkan bahwa selain mengakibatkan kematian, poliploidisasi dengan kolkisina juga mampu meningkatkan daya regenerasi. Hasil penelitian serupa pernah dilaporkan oleh Fras dan Maluszynska (2003), bahwa kalus yang berasal dari daun tanaman tetraploid hasil perlakuan kolkisina menunjukkan kemampuan regenerasi paling tinggi.

Frekuensi regenerasi menggambarkan kemampuan eksplan untuk beregenerasi sampai membentuk planlet lengkap. Frekuensi regenerasi yang besar pada eksplan hasil pemeraman kolkisina 72 jam (87\%) dan 24 jam (61,5\%) diikuti dengan banyaknya jumlah tunas yang mampu diregenerasikan (474 dan 45). Dibanding rerata kontrol pada kedua parameter tersebut, planlet hasil pemeraman kolkisina 72 jam dan 24 jam lebih unggul, sedangkan pemeraman 48 jam paling rendah (30\%). Sementara dibandingkan dengan rerata jumlah tunas seluruh perlakuan $(134,61)$, hanya hasil pemeraman kolkisina 72 jam yang lebih unggul. Ini menunjukkan bahwa ada faktor yang membatasi hubungan antara frekuensi regenerasi eksplan dengan kecenderungan banyaknya jumlah tunas yang diregenerasikan.

Ketidaksesuaian dengan media tanam diduga merupakan faktor yang menghambat regenerasi planlet hasil pemeraman kolkisina 48 jam dan 24 jam. Sebagai hasil dari tata cara yang tergolong mutagenesis (proses mengubah informasi genetik), keragaman individu dalam populasi yang diberi perlakuan kolkisina secara in vitro merupakan kelaziman, termasuk keragaman dalam tanggapan terhadap media tanam yang digunakan. Dugaan ini diperkuat dengan adanya gejala stagnasi yang tampak pada kebanyakan kalus dari planlet hasil pemeraman kolkisina 48 jam dan 24 jam. Pierik (1997) pernah mengemukakan bahwa perkembangan kalus yang stagnan setelah pindah tanam mengindikasikan bahwa media yang digunakan tidak sesuai. Kadang perkembangan lanjutan kalus pada media sintetis tidak dimungkinkan, sehingga perlu ditambahkan campuran senyawa kompleks seperti air kelapa muda. 
Fathin Nabihaty et al., / Vegetalika. 2018. 7(1): 26-38

Tabel 1. Karakter morfologi dan regenerasi planlet Rimbang hasil poliploidisasi

\begin{tabular}{|c|c|c|c|c|c|c|c|c|c|}
\hline \multirow[b]{2}{*}{$\begin{array}{c}\text { Waktu } \\
\text { Pemeraman } \\
\text { dengan } \\
\text { Kolkisina } \\
\end{array}$} & & \multicolumn{5}{|c|}{ Morfologi } & \multicolumn{3}{|c|}{ Regenerasi } \\
\hline & $\mathrm{n}$ & $\begin{array}{l}\text { Tinggi } \\
\text { Tunas } \\
(\mathrm{cm})\end{array}$ & $\begin{array}{l}\text { Jumlah } \\
\text { Nodus } \\
\text { Daun }\end{array}$ & $\begin{array}{l}\text { Warna } \\
\text { Daun } \\
\text { (BWD) }\end{array}$ & $\begin{array}{l}\text { Panjang } \\
\text { Akar } \\
(\mathrm{cm})\end{array}$ & $\begin{array}{l}\text { Rasio } \\
\text { Akar/ } \\
\text { Tunas }\end{array}$ & $\begin{array}{l}\text { Jumlah } \\
\text { Tunas }\end{array}$ & $\begin{array}{l}\text { Rerata } \\
\text { Jumlah } \\
\text { Tunas/ } \\
\text { Eksplan }\end{array}$ & $\begin{array}{l}\text { Frekuensi } \\
\text { Regenerasi } \\
\text { (\%) }\end{array}$ \\
\hline Kontrol & 26 & 6,44 & 10,07 & 1,92 & 10,00 & 1,77 & 16,44 & 5,71 & 37,8 \\
\hline 24 jam & 24 & 4,98 & 8,5 & 2,2 & 7,09 & 1,95 & 45,0 & 3,9 & 61,5 \\
\hline 48 jam & 5 & 2,08 & 8,3 & 2,0 & 4,29 & 1,35 & 3,0 & 1,5 & 30,0 \\
\hline 72 jam & 86 & 4,25 & 6,1 & 2,4 & 5,17 & 2,78 & 474,0 & 5,5 & 87,0 \\
\hline Rerata & & 4,44 & 8,26 & 2,14 & 6,64 & 1,96 & 134,61 & 4,16 & $54,06^{\prime}$ \\
\hline
\end{tabular}

Seluruh planlet terung yang berhasil beregenerasi membentuk planlet dalam penelitian ini diperoleh dari jenis Rimbang. Sementara eksplan dari jenis terung lainnya tidak ada satu pun yang mampu membentuk planlet lengkap. Sebagian hanya memunculkan akar dan sebagian lainnya hanya membentuk kalus stagnan (Lampiran 5). Kebanyakan eksplan Terung Pipit memunculkan akar lebih dahulu dan tidak dapat membentuk tunas meski sudah dipindahkan ke media tanpa hormon dan media dengan tambahan $3 \mathrm{mg} / \mathrm{l} \mathrm{BAP}$. Selain faktor eksternal dari media dan dosis kolkisina, daya regenerasi juga dipengaruhi faktor internal, antara lain genetik dan umur planlet induk. Pierik (1997) menjelaskan bahwa kalus dan akar lebih mudah terbentuk ketika diinduksi dari tanaman muda (juvenile) dari pada tanaman dewasa (adult). Namun demikian, hasil pengamatan menunjukkan bahwa tunas sulit muncul ketika akar telah muncul dahulu. Besarnya frekuensi regenerasi planlet Rimbang juga dipengaruhi oleh kedua faktor tersebut. Rimbang termasuk jenis tanaman invasif yang sangat mudah beradaptasi pada lingkungan baru, sedangkan umur induk Rimbang yang digunakan merupakan yang paling dewasa dibanding jenis lainnya.

Hasil pengamatan individual menunjukkan bahwa $81 \%$ planlet beregenerasi melalui tahap pembentukan kalus (Lampiran 5), atau disebut jalur organogenesis tidak langsung. Kalus, menurut Pierik (1997) merupakan sel tumor yang terbentuk setelah dediferensiasi dan membelah terus menerus secara intensif. Tahap pembentukan kalus penting bagi eksplan yang hanya mengandung sel parenkim terdiferensiasi, yaitu sebagai suatu proses de-diferensiasi dan peremajaan kembali (rejuvenation), sehingga kemudian sel-selnya memiliki kemampuan pertumbuhan, pembelahan, dan rediferensiasi yang lebih besar dari pada sel dewasanya. Selain itu, kemunculan kalus juga merupakan petunjuk awal dimulainya proses regenerasi.

Tanda awal pembentukan kalus secara kasat mata (Gambar 4.2) paling cepat terlihat di hari ke-4, dimulai dengan perubahan bentuk daun menjadi berkerut dan melekuk, pada eksplan tampak ada bagian yang mengalami pertambahan jumlah atau ukuran, sementara bagian lainnya tidak. Perkembangan yang tidak seragam pada satu 
eksplan daun terjadi karena kompleksitas jaringan penyusunnya, sementara tipe jaringan yang berbeda juga membentuk kalus secara berbeda. Pierik (1997) menyatakan bahwa kalus bisa tampak sangat tidak homogen karena terdiri dari dua macam sel, yaitu sel terdiferensiasi dan tidak terdiferensi. Sementara itu, disebutkan oleh Davidson (2015) bahwa sebagaimana organ tumbuhan lainnya, daun terdiri dari tiga sistem jaringan utama, yaitu jaringan dermal, pembuluh, dan dasar. Namun demikian, komponen penyusunnya berbeda sangat signifikan, yaitu terdiri dari epidermis, kutikula, stomata, sel penjaga, jaringan pembuluh utama (tersusun dari xylem dan floem), serta mesofil (tersusun dari palisade parenkim, spons parenkim, dan kolenkim).

Di hari ke-7 kebanyakan eksplan telah menunjukkan perubahan bentuk dan mulai memunculkan kalus berwarna putih susu atau kehijauan pada bagian yang luka (Gambar 4.2). Pemindahan semua eksplan dari media pra-perlakuan ke media perlakuan yang mengandung kolkisina dilakukan 1-2 hari setelahnya. Meski perkembangan antar eksplan tidak sama, eksplan yang belum menunjukkan perubahan tetap dipindahkan pada hari ke-7 untuk menyamakan tata cara pra-perlakuan kolkisina.

Kebanyakan eksplan yang mengalami pencokelatan atau browning (Gambar 2.e; 2.f; dan 2.h) pada akhirnya mati atau perkembangannya stagnan pada fase kalus, dan tidak dapat membentuk planlet. Menurut Ahmad et al. (2013), pencokelatan pada kalus merupakan hasil oksidasi fenol oleh enzim Polyphenol Oxidase (PPO). Fenol merupakan metabolit sekunder yang dilepaskan dari bagian eksplan yang terluka sebagai mekanisme pertahanan terhadap cekaman. Produk dari reaksi ini adalah kuinon, senyawa yang sangat reaktif dan beracun terhadap jaringan tanaman. Kuinon memasuki jaringan secara bertahap dan menekan aktivitas enzim, sehingga meracun dalam media; menghambat pertumbuhan sel, kemudian menghambat diferensiasi tunas dan pengakaran, serta mengakibatkan kematian. Meski demikian, beberapa eksplan masih dapat berkembang sampai membentuk kalus, seperti Terung Hijau Malang dan Pipit (Gambar 2.g dan 2.i). Keparahan pencokelatan berbeda antar spesies, varietas, jaringan, umur dan fase perkembangan organ. Sementara resiko kematian (lethal) akibat ini dicegah dengan cara pindah tanam (sub-culture) atau menggunakan absorben dan antioksidan (Ahmad et al., 2013). 

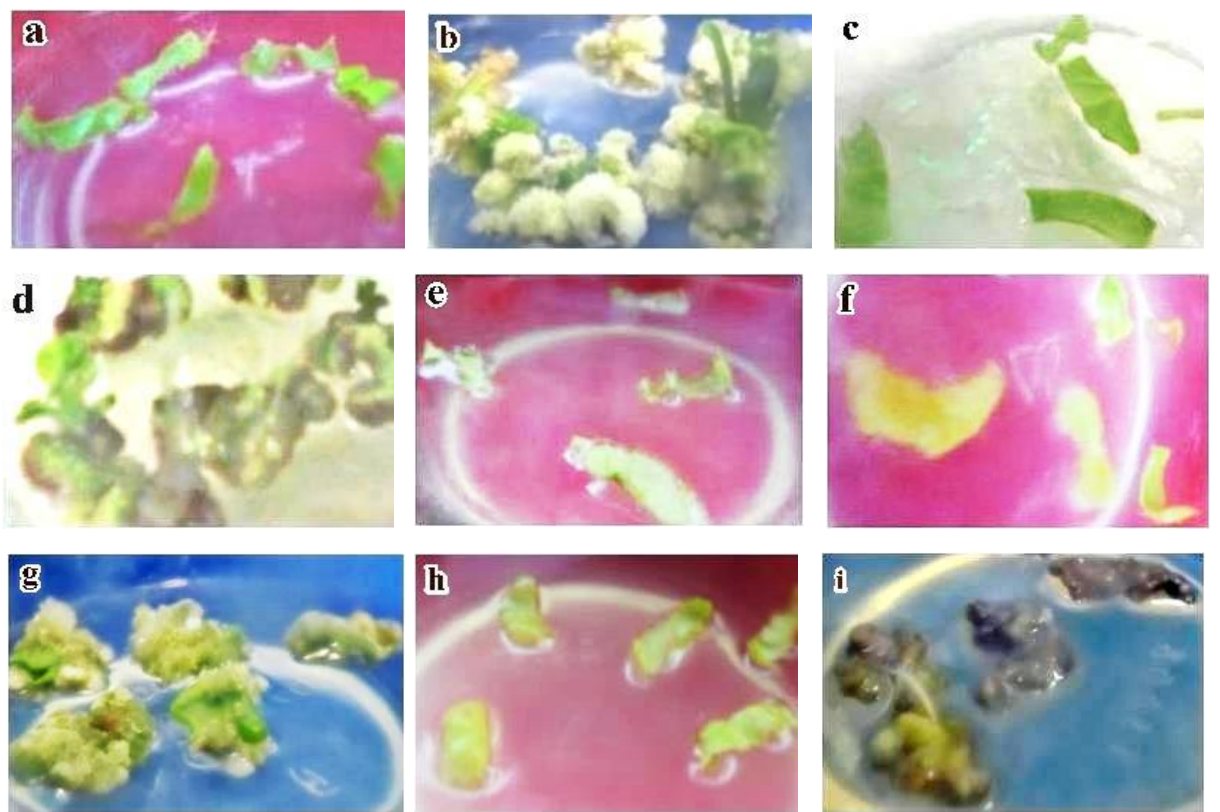

Gambar 2. Awal perkembangan eksplan: (a) Terung Lokal Bantul hari ke-8 dan (b) hari ke-47; (c) Rimbang hari ke-10 dan (d) hari ke-57; (e) Limao hari ke-10; (f) Hijau Malang hari ke-9 dan (g) hari ke-33; (h) Pipit hari ke-10 dan (i) hari ke-33

Perbedaan kemampuan pembentukan kalus dari eksplan yang setipe terutama disebabkan adanya perbedaan permiabilitas jaringan (Dhooghe et al., 2011) dan hormon endogen (Pierik, 1997), yang dalam penelitian ini dapat timbul sebagai konsekuensi dari perbedaan karakteristik daun (dari jenis tanaman yang berbeda), posisi, dan umur daun saat diambil dari tanaman induknya. Filek et al. (2004) menyatakan bahwa konsentrasi (auksin) Indole Acetic Acid (IAA) endogen pada kalus embriogenik lebih tinggi dari pada kalus non-embriogenik. Meski berasal dari eksplan yang sama, perbedaan permiabilitas membran dan respon terhadap hormon antara kalus embriogenik dan non-embriogenik dapat terjadi disebabkan perbedaan struktur lipid. Komposisi asam lemak tak jenuh lebih tinggi pada membran sel embriogenik. Sitokinin bekerja lebih baik dalam meningkatkan permiabilitas dan menurunkan rasio fosfolipid pada sel embriogenik, yaitu dengan cara mereduksi rasio fosfolipid/sterol sehingga sel yang berinteraksi dengan fitohormon menjadi berkurang. Dhooghe et al.(2011) menyatakan jika pada gilirannya perbedaan permiabilitas jaringan ini dapat mempengaruhi keberhasilan poliploidisasi.

Selanjutnya, perbedaan kemampuan regenerasi dari eksplan yang setipe terkait dengan kualitas kalus yang terbentuk (Tian et al., 1994). Eksplan yang berhasil beregenerasi dengan frekuensi regenerasi yang besar diperoleh dari botol-botol pembudidayaan yang eksplannya segera dipindahkan ke media media perlakuan setidaknya 24 jam setelah mulai muncul kalus, kemudian membentuk tunas lebih dahulu sebelum akar. Hanya satu eksplan Rimbang hasil perlakuan kolkisina 48 jam yang 
memunculkan akar lebih dahulu kemudian mampu melanjutkan regenerasi hingga membentuk planlet lengkap. Menurut Tian et al. (1994), perbaikan kualitas kalus pada tahap induksi mampu meningkatkan frekuensi regenerasi. Perbaikan kualitas kalus menurut Pierik (1997) dapat dilakukan dengan cara pindah tanam (sub-culture
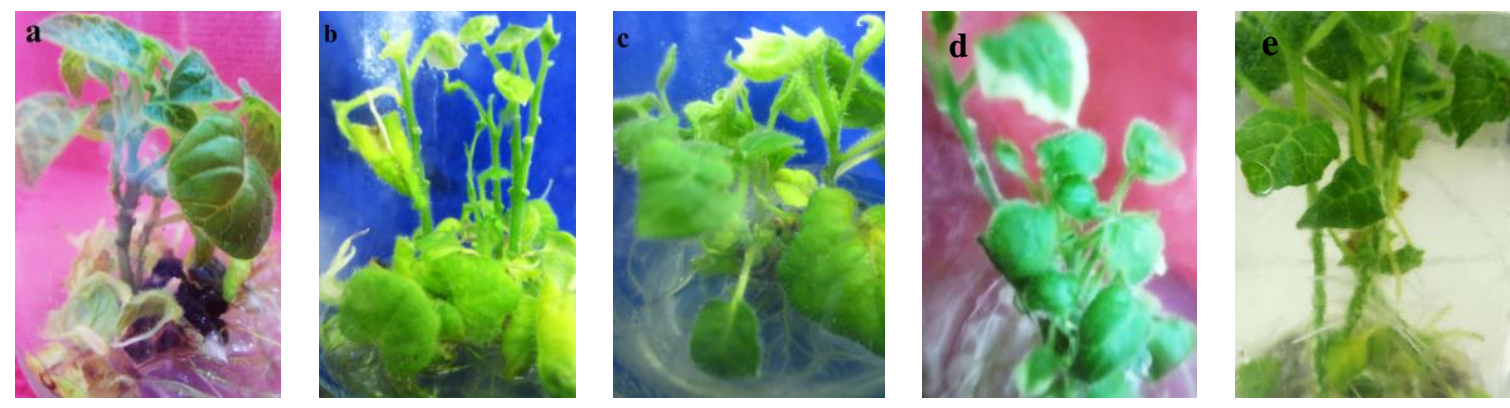

Gambar 3. Abnormalitas pertumbuhan dan morfologi (umur $13 \mathrm{mst}$ ) berupa (a) gugur pada daun R224 yang kehijauannya telah menurun dan (b) R112 yang kehijauannya masih cukup tinggi, serta (c) kenampakan planlet yang kerdil pada R312, dan (d) variegata pada R315, dibandingkan (e) planlet kontrol R04.4

Pertumbuhan planlet hasil poliploidisasi in vitro yang abnormal (Gambar 3) dapat disebabkan oleh perubahan struktural (penggandaan atau kehilangan) yang terjadi pada bahan genetik (mutasi) dan/atau ekspresi genetik (epigenetik) (Dhooghe et al., 2011). Individu yang mengalami mutasi biasanya memiliki kemampuan berbeda dalam memproduksi hormon-hormon endogen, khususnya asam absisat / ABA (Abscisic Acid) dan etilen. Finkelstein (2013) melaporkan bahwa mutan biosintan etilen memproduksi ABA berlebih dan mengalami pengguguran organ (abscission) sebagai tanggapan terhadap cekaman, sedangkan mutan yang kekurangan ABA tampak kerdil karena ketidakmampuannya menghambat produksi etilen. Sebelumnya juga telah dilaporkan oleh Dhooghe et al., (2011) bahwa tetraploid pada banyak jenis tanaman meningkatkan ketahanannya terhadap cekaman kekeringan. Sedangkan daun variegata (berpola) menurut Marcotrigiano (1997) bisa jadi terkait dengan kimera.

Berdasarkan pengamatan morfologi secara umum (Tabel 1), diketahui bahwa planlet yang dikontrol tanpa kolkisina menghasilkan nilai ketinggian tunas $(6,44 \mathrm{~cm})$, panjang akar $(10 \mathrm{~cm})$ dan jumlah nodus daun $(10,07)$ paling besar, kemudian disusul oleh planlet hasil perlakuan pemaparan kolkisina selama 24 jam $(4,98 \mathrm{~cm} ; 7,09 \mathrm{~cm}$; dan $8,5)$. Kedua perlakuan tersebut memiliki nilai di atas rerata seluruh perlakuan $(4,44 \mathrm{~cm}$; $6,64 \mathrm{~cm}$; dan 8,26). Akan tetapi, tidak ada satupun dari seluruh perlakuan kolkisina yang nilainya lebih tinggi dibanding kontrol tanpa kolkisina. Oleh sebab itu, dimungkinkan ada hubungan lebih kompleks antar beberapa parameter pertumbuhan/morfologi planlet hasil poliploidisasi, semisal tinggi tunas dan panjang akar. 
Hubungan antara tunas dan akar dituliskan dalam bentuk perbandingan atau rasio, yang merupakan pengaruh faktor hormon-hormon yang aktif sejak awal tahap diferensiasi. Rasio akar:tunas terbesar didapat dari perlakuan kolkisina 72 jam, nilai yang diperoleh $(2,78)$ lebih tinggi dari rerata seluruh perlakuan $(1,96)$ dan rerata kontrol $(1,77)$. Menurut Finkelstein (2013), peningkatkan rasio akar:tunas terkait tingkat ABA yang agak tinggi dalam kondisi cekaman air ringan. Sedangkan menurut Hameed et al. cit Atichart (2013), peningkatan jumlah tunas aksiler dan penekanan panjang tunas disebabkan penggunaan BAP yang merupakan sitokinin kuat. Kedua jenis hormon tersebut mungkin berinteraksi dengan faktor genetik individu hasil poliploidisasi, karena hasil pengamatan individual menunjukkan adanya keragaman rasio akar:tunas, jumlah, dan tinggi tunas dalam perlakuan. Penekanan tinggi tunas diduga cukup mempengaruhi kerapatan nodus pada inividu yang lemah, sehingga regenerasi dan pertumbuhan menjadi terhambat, seperti pada kebanyakan individu hasil perlakuan kolkisina 48 jam. Jumlah nodus daun biasanya menunjukkan umur vegetatif yang sebanding dengan tinggi tunas, namun hasil pengamatan pada planlet hasil perlakuan kolkisina 48 jam menunjukkan abnormalitas, yaitu jumlah nodus dalam satu tunas cukup banyak $(8,3)$ dengan jarak antar nodus sangat rapat (Gambar 3.a).

Ciri morfologi lain yang menjadi penduga kuat poliploid adalah kehijauan daun. Perlakuan kolkisina secara umum tampak jelas meningkatkan kehijauan daun dari rerata $(2,14)$ seluruh perlakuan (Tabel 1), namun hanya planlet hasil perlakuan kolkisina 24 jam $(2,2)$ dan 72 jam $(2,4)$ yang nilainya lebih tinggi dari rerata kontrol $(1,92)$. Dhooghe, et al. (2011) menyatakan bahwa hasil penggandaan kromosom dapat tampak pada warna hijau daun yang lebih pekat dan peningkatan ketebalan daun. Di samping kehijauan, ciri morfologi lain dari daun yang dijadikan penduga poliploid lainnya dalam penelitian ini adalah bentuk daun. Meski tidak banyak laporan mengenai ini, namun beberapa penelitian telah membuktikan adanya kaitan antara mutasi genetik yang terjadi dalam satu populasi dengan keragaman bentuk daun yang didapatkan, semisal penelitian yang dilakukan oleh Serrano-cartagena et al. (1999) pada tanaman Arabidopsis.

Seluruh nilai karakter morfologi planlet yang diberi perlakuan kolkisina dibandingkan secara individual dengan rerata kontrol, sehingga diperoleh 67 nomor individu yang terduga mutan poliploid, yaitu: 16 nomor dari hasil perlakuan kolkisina 24 jam, 1 nomor dari hasil perlakuan kolkisina 48 jam, dan 50 nomor dari hasil perlakuan kolkisina 72 jam. Sejumlah planlet yang diduga poliploid tersebut jika dibandingkan dengan keseluruhan 113 planlet yang berhasil diregenerasikan diperoleh nilai 59\% yang 
menunjukkan besaran efisiensi poliploidisasi. Menurut Dhooghe et al. (2011), keberhasilan induksi poliploid merupakan hasil saling keterkaitan antara toksisitas dan efisiensi poliploidisasi. Pencokelatan, stagnasi pertumbuhan, dan gugur daun merupakan dampak toksisitas kolkisina yang mungkin berpengaruh terhadap kegagalan regenerasi $41 \%$ kalus dan planlet dalam penelitian ini.

Kromosom sel dari planlet yang dikontrol tanpa kolkisina pada hasil pengamatan (Gambar 4.a) diketahui berjumlah $2 n=2 x=24$, sesuai dengan laporan sebelumnya oleh Bernardello et al. (1994) yang menyebutkan bahwa kebanyakan anggota sub-famili Solanoideae merupakan diploid dengan $n=12$, sehingga $2 n=2 x=24$. Jumlah kromosom yang sama didapatkan dari sel-sel planlet pertama hasil perlakuan kolkisina 72 jam (Gambar 4.d). Selain dari jumlah kromosom, kesamaan keduanya juga tampak serupa pada ukuran sel, ketebalan dinding sel, dan panjang kromosom relatif, sehingga dapat dipastikan bahwa planlet ini tidak mengalami penggandaan kromosom.

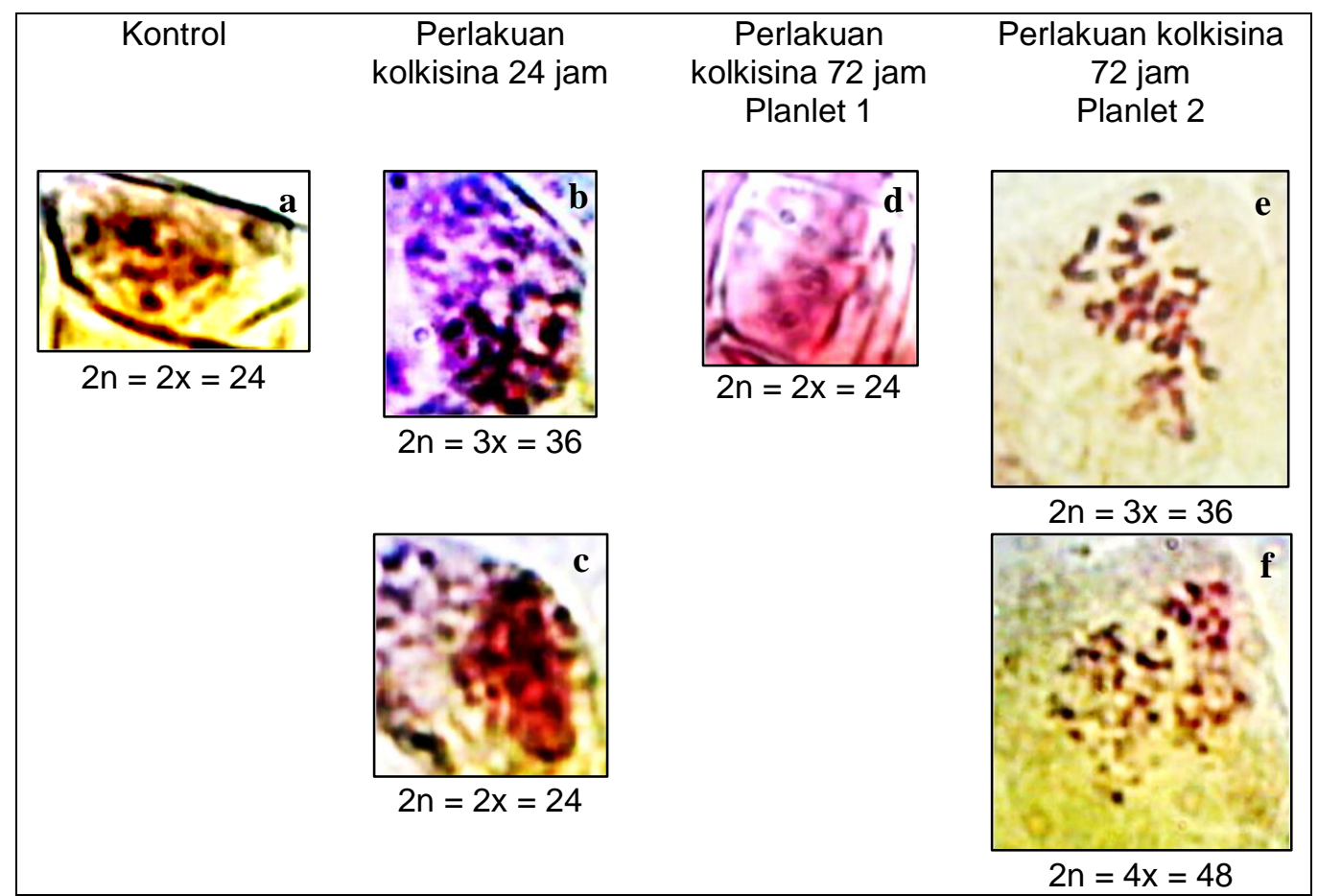

Gambar 4. Sel Terung Rimbang hasil poliploidisasi (perbesaran 1000 kali)

Perbedaan yang cukup jelas ketika dibandingkan dengan sel dari planlet kontrol tampak pada sebagian sel planlet hasil perlakuan kolkisina 24 jam dan sel-sel planlet kedua hasil perlakuan kolkisina 72 jam. Bentuk sel pada kedua planlet tersebut cukup beragam, dengan ukuran yang relatif lebih besar dibanding kontrol. Kromosom pada keduanya juga tampak lebih pendek, tebal, dan rapat. Perubahan kenampakan properti sel tersebut dimungkinkan akibat pengaruh kolkisina. Menurut Oejiewo et al. (2007), peningkatan ukuran genom biasanya terjadi selama organogenesis pada poliploidisasi 
Fathin Nabihaty et al., / Vegetalika. 2018. 7(1): 26-38

yang sistemik di spesies angiosperma melalui endo-reduplikasi yang melibatkan replikasi Deoxyribonucleic Acid (DNA) tanpa pemisahan sel, sehingga menghasilkan sel dengan nukleus yang lebih besar dari pada nukleus sel diploid. Gagalnya pemisahan sel dapat terjadi karena menurut Dhooghe et al., (2011), kolkisina berasosiasi dengan dimer $\alpha$ - dan $\beta$-tubulin, sehingga mikrotubulus terdepolimerisasi.

Kedua contoh planlet yang diketahui mixoploid tersebut merupakan hasil regenerasi ketiga (tersier) yang merupakan representasi dari planlet hasil regenerasi pertamanya. Gambar 5 menunjukkan adanya kesamaan karakter umum masing-masing planlet mulai dari hasil regenerasi pertama sampai regenerasi ke tiga, meskipun juga tampak adanya satu perbedaan yaitu penurunan ketinggian tunas yang dimungkinkan terkait pengaruh hormon. Kesamaan umum ini menunjukkan adanya kesamaan genetik yang diwariskan antar generasi planlet tersebut, serta tidak berubah selama 3-4 kali proses pindah tanam dan 2 kali siklus regenerasi ulang. Banyak laporan menyebutkan bahwa mixoploid dapat dipisahkan dengan pemindahan media terus menerus, namun berdasarkan laporan Poerba et al. (2014) pada tanaman pisang diketahui bahwa mixoploid masih stabil dan belum dapat dipisahkan hingga 6 kali pemindahan media dan 2 kali siklus regenerasi ulang planlet
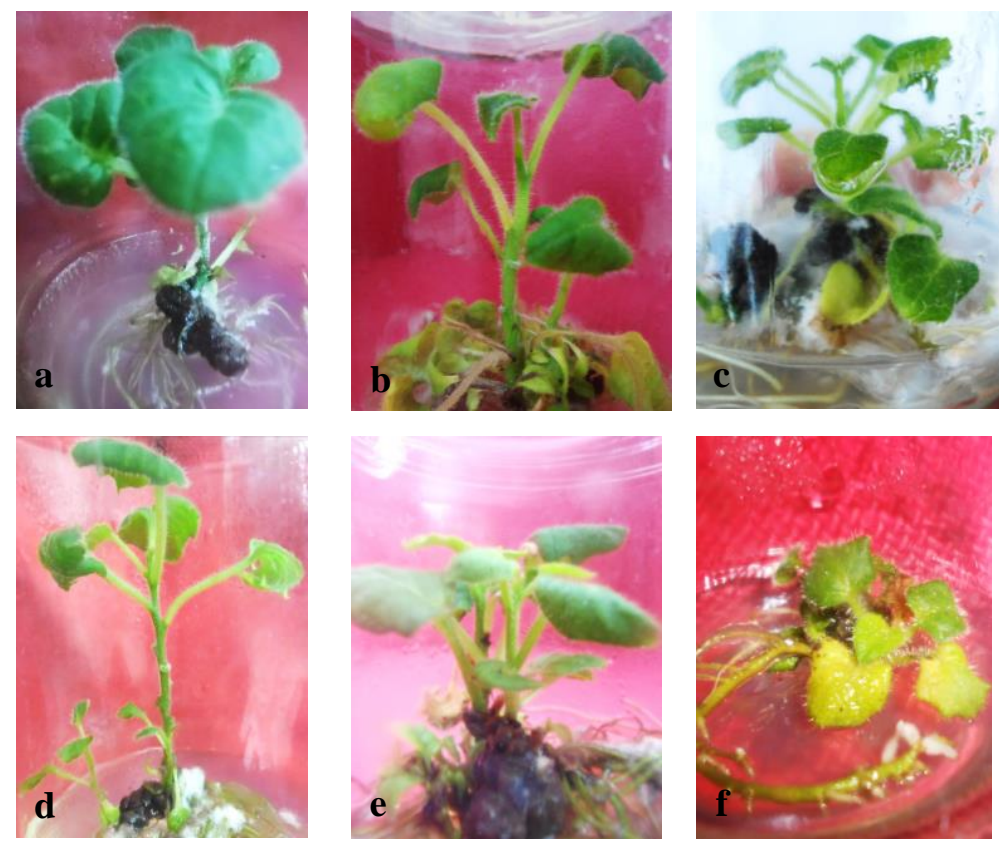

Gambar 5. Perbandingan morfologi planlet poliploid Rimbang hasil regenerasi pertama sampai regenerasi ke tiga. Planlet (a), (b), (c) dari perlakuan kolkisina 24 jam; dan (d), (e), (f) dari perlakuan kolkisina 72 jam

Terbuktinya keberadaan poliploid pada kedua contoh planlet berdasarkan hasil pengamatan jumlah kromosom cukup memberikan konfirmasi bagi seleksi poliploid 
sebelumnya dengan kriteria morfologi planlet. Ploidi tertinggi yang diperoleh dari perlakuan kolkisina 72 jam menunjukkan bahwa dosis $2,5 \mathrm{mM}$ kolkisina dengan waktu pemeraman tersebut merupakan yang terbaik, karena menurut Dhooghe et al. (2011) tingkat penggandaan kromosom dalam poliploidisasi dipengaruhi oleh intensitas pemaparan terhadap mutagen. Namun demikian, banyak faktor lain dalam poliploidisasi yang tidak dapat diabaikan karena mempengaruhi tingkat keberhasilan poliploidisasi, yaitu genetik (kultivar); umur eksplan; umur dan fase pertumbuhan tanaman induk; komposisi media tanam; dan kondisi fisik lingkungan.

\section{KESIMPULAN}

1. Pengaruh pemeraman eksplan daun dengan $2,5 \mathrm{mM}$ kolkisina secara in vitro terhadap keberhasilan pembentukan terung tetraploid tampak pada skala makroskopis dan mikroskopis. Pengaruh pada skala mikroskopis ditunjukkan dengan ukuran nukleus yang membesar, kromosom yang memendek, lebih banyak, dan rapat, sedangkan pengaruh pada skala makroskopis ditunjukkan dengan peningkatan kehijauan daun, bentuk daun, rasio akar:tunas, jumlah tunas, dan frekuensi regenerasi.

2. Tata cara poliploidisasi yang digunakan dalam penelitian ini berhasil membentuk poliploid dengan efisiensi $59 \%$, terdiri dari poliploid $2 x+3 x$ dan $3 x+4 x$.

3. Poliploid yang berhasil diregeneasikan berasal dari kultivar Rimbang, yang diperkirakan jumlahnya sebanyak 67 planlet.

4. Planlet yang mengandung sel tetraploid sekaligus tingkat ploidinya tertinggi diperoleh dari perlakuan kolkisina selama 72 jam.

\section{DAFTAR PUSTAKA}

Ahmad, I., T. Hussain., I. Ashraf, M. Nafees, Maryam, M. Rafay, M. Iqbal. 2013. Lethal effects of secondary metabolites on plant tissue culture. American Eurasian J. Agric. and Environ. Sci. 13: 539-547.

Atichart, P. 2013. Polyploid induction by colchicine treatment and plant regeneration of Dendrobium chrysotoxum. Thai Journal of Agricultural Science 46: 59-63.

Bernardello, L.M., C.B. Heiser and M. Piazzano. 1994. Kariotypic studies in Solanum section Lasiocarpa (Solanaceae). American Journal of Botany 81: 95-103 (Abstr.)

Collins, G.B. 1979. Cytogenetic techniques. Nicotiana procedures for experimental use. Technical Bulletin 1586: 17-21. 
Fathin Nabihaty et al., / Vegetalika. 2018. 7(1): 26-38

Davidson, $\quad$ M.W. 2015. Leaf Tissue Organization. http://micro.magnet.fsu.edu/cells/leaftissue.html. Diakses tanggal 10 Mei 2017.

Dhooghe, E., K. van Laere, T. Eeckhaut, L. Leus, J. van Huylenbroeck. 2011. Mitotic chromosome doubling of plant tissues in vitro. PCTOC 104: 359-373.

Erniwitama. 2013. Pengaruh Jenis Eksplan dan Konsentrasi BAP terhadap Kemampuan Regenerasi Beberapa Kultivar Terung. Fakultas Pertanian. Universitas Gadjah Mada. Tesis.

Filek M., J. Biesaga-Koscielniak, I. Marcinska, I. Machackova, J. Krekule. 2004. The influence of growth regulators on membrane permeability in cultures of winter wheat cells. Naturforsch 59: 673-687.

Finkelstein, R. 2013. Abscisic acid synthesis and response. Arabidopsis Book 11. https://www.ncbi.nlm.nih.gov/pmc/articles/PMC3833200/. Diakses 9 Mei 2017.

Fras, A. and J. Maluszynska. 2003. Regeneration of diploid and tetraploid plants of Arabidobsis thaliana via Callus. Acta Biologica 45: 145-152.

Jelenic, S., J. Berljak, D. Papes, S. Jelaska. 2001. Mixoploidy and chimeric structures in somaclones of potato (Solanum tuberosum L.) cv. Bintje. Food Technol. Biotechnol. 39: 13-17.

Kihara, H. 1951. Triploid watermelon. Proc. Amer. Soc. Hort. Sci. 58: 217-230.

Marcotrigano, M. 1997. Chimeras and variegation: patterns of deceit. Hort. Science 32: 773-784.

Ojiewo, C.O., K. Murakami, P.W. Masinde, and S.G. Agong. 2007. Polyploidy breeding of African Nightshade (Solanum section Solanum). International Journal of Plant Breeding 1: 10-21.

Pardal, S.J. 2009. Rekayasa buah tanpa biji. Warta Penelitian dan Pengembangan Pertanian Indonesia 31: 9.

Pierik, R.L.M. 1997. In Vitro Culture of Higher Plants. Kluwer Academic Publisher, Dordrecht.

Poerba, Y.S., Witjaksono, F. Ahmad, T. Handayani. 2014. Induksi dan karakterisasi Pisang Mas Lumut Tetraploid. Jurnal Biologi Indonesia 10: 191-200.

Serrano-cartagena, J., P. Robles, M.R. Ponce, J.L. Micol. 1996. Genetic analysis of leaf form mutants from the Arabidopsis Information Service collection. Mol. Gen Genet. 261: 725-39.

Tian, W., I. Rance, E. Sivamani, C. Fauquet, R.N. Beachy. 1994. Improvement of plant regeneration frequency in vitro in Indica Rice. Chinese Journal of Genetics 21: 18.

Yi, L., D. Hui, H.W. Yan, R.J. McAvoy, P. Yan, Z. Degang, W. John, L. Qi, and L. Keming. 2004. Transgenics of Plant Hormones and Their Potential Application in Horticultural Crops. In: G.H. Liang and D.Z. Skinner (Eds.). Genetically Modified Crops: Their Development, Uses, and risks. The Haworth Press, Inc., New York, p: $100-104$ 